\title{
BIOREMEDIATION FOR ACID MINE DRAINAGE: ORGANIC SOLID WASTE AS CARBON SOURCES FOR SULFATE-REDUCING BACTERIA: A REVIEW
}

\author{
I. N. Jamil ${ }^{1}$ and William P. Clarke ${ }^{2}$ \\ ${ }^{1}$ Faculty of Science, University of New South Wales, Australia \\ ${ }^{2}$ School of Civil Engineering, The University of Queensland, Australia \\ Email: ili.jamil@gmail.com
}

\begin{abstract}
Biological sulfate reduction has been slowly replacing chemical unit processes to treat acid mine drainage (AMD). Bioremediations for AMD treatment are favored due to their low capital and maintenance cost. This paper describes the available AMD treatment, current SRB commercialization such as THIOPAQ ${ }^{\circledR}$ and BioSulphide ${ }^{\circledR}$ technologies, and also the factors and limitations faced. THIOPAQ ${ }^{\circledR}$ and BioSulphide ${ }^{\circledR}$ technologies use expensive carbon sources such as hydrogen as the electron donor. This paper discusses the possibility of organic solid waste as an alternative substrate as it is cheaper and abundant. A possible AMD treatment system setup was also proposed to test the efficiency of sulfate-reducing bacteria utilizing organic solid substrate.
\end{abstract}

Keywords: Acid mine drainage; biological treatment; bioremediation; sulfate-reducing bacteria: carbon source.

\section{INTRODUCTION}

A substantial number of investigations have been done by various institutes, private companies and universities regarding the development of biological processes for application in the mining and metallurgical industry (van Houten, Pol, \& Lettinga, 1994). These investigations mainly focus on treating acid mine drainage (AMD) wastewater formed in the mining and metallurgical industries. In recent years, improvements have been made in the designs, constructions and operation of aerobic and anaerobic bioreactors for bioremediation to treat AMD. Bioremediation in mine treatment was ignited due to the need for waste management and handling, especially in the urban world. In recent years, global awareness of environmental effects has increased due to the depletion of valuable and non-renewable resources. In response, some local governments have taken their own initiatives to improve waste management and handling. An example of these initiatives can be seen with the Waste Reduction and Recycling Bill 2011 by the Queensland State Government. This bill requires waste management operators to practice under a new pricing regime of $\$ 35$ per ton of waste received (Government, 2011). One of the sources of AMD is from the by-products of metal mines or coal mines, and it occurs when sulfide-bearing material is exposed to oxygen and water. This is one of the major environmental issues associated with the mining industries. The effluent generated by metallurgy mines contains toxic substances such as heavy metals and cyanides in abundant quantities (Akcil \& Koldas, 2006). AMD can be characterized by having a low $\mathrm{pH}$ and high concentration of heavy metals and other toxic substances, which can cause severe surface and ground water contamination (Peppas, Komnitsas, \& Halikia, 2000). AMD characteristics differ from 
site to site due to the presence of different minerals (Government, 2007). Pollution control of AMD is achievable by preventing AMD formation, migration and/or collection treatment (Kaksonen \& Puhakka, 2007; Sundar Raj \& Sendilvelan, 2010; Tangjitsitcharoen \& Nunya, 2011). This review is an overview to identify the knowledge gaps in bioremediation of acid mine drainage (AMD), where organic solid waste as well as municipal solid waste are considered as alternative substrates or carbon sources.

\section{ACID MINE DRAINAGETREATMENTS}

A collection and treatment method is the key factor in the management and control strategy used in AMD treatment. This strategy consists of the collection of all contaminated mine wastes to be treated by either chemical or biological processes, with the aim of neutralizing the acidity, and removing metal species and suspended solids. A traditional method for treating AMD consists of neutralizing the acidity with alkali, increasing the water $\mathrm{pH}$, and precipitating metals such as hydroxides and carbonates. Other treatments include ion exchange, reverse osmosis and electro-dialysis, but are not favored due to their high operational costs. Biological treatment for sulfate reduction is gradually replacing the chemical unit treatment. Biological treatment, also known as bioremediation, employs sulfate-reducing bacteria (SRB) to treat ground and surface water contaminated by AMD. SRB are able to produce biogenic $\mathrm{H}_{2} \mathrm{~S}$, which can be used to react with heavy metals, resulting in the precipitation of metal sulfides. Biogenic alkalinity is also a by-product of SRB, which is used to neutralize acidic water. Bioremediation can be classified into passive biological treatment and active biological treatment, and Table 1 gives a brief summary of these treatments.

Table 1.Comparison between passive and active treatment.

\begin{tabular}{lcc}
\hline \multicolumn{1}{c}{ Method } & Passive & Active \\
\hline Cost & Low & High \\
Labor requirement & Small & High \\
Treatment area & Large & Small \\
Metal recovery & Difficult & Easy \\
Control & Poor & Good \\
Predictability & Poor & Good \\
\hline
\end{tabular}

This paper will be looking into active biological treatment and the current commercialization of this treatment. Table 2 presents a summary of the advantages and disadvantages of various reactor types that can be applied in this research. An active treatment system is typically a continuous process and involves at least one reactor. This allows a precise process control and this system also allows modifications of functions in a biological system. One of the setbacks of bioremediation is that the start-up of a biological reactor system is harder than the conventional chemical process treatment. The mechanisms of the biological system are currently not fully understood, thus the fundamental knowledge regarding the microbial community and key parameters are needed for the improvement of this treatment. 
Table 2. Summary of various reactor configurations.

\begin{tabular}{|c|c|c|}
\hline Reactor Configuration & Advantages & Disadvantages \\
\hline $\begin{array}{l}\text { Continuous stirred } \\
\text { tank reactor(CSTR) }\end{array}$ & 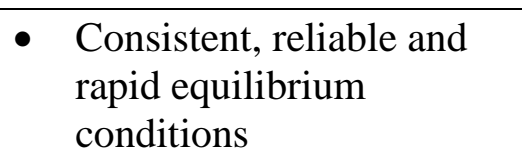 & $\begin{array}{l}\text { - Poor retention of } \\
\text { biomass }\end{array}$ \\
\hline $\begin{array}{l}\text { Anaerobic contact } \\
\text { process (ACP) }\end{array}$ & $\begin{array}{l}\text { - Better retention of } \\
\text { biomass compared to } \\
\text { CSTR }\end{array}$ & $\begin{array}{l}\text { Pumping of biomass } \\
\text { breaks down flocks } \\
\text { and sludge }\end{array}$ \\
\hline $\begin{array}{l}\text { Anaerobic filter } \\
\text { reactor }\end{array}$ & $\begin{array}{l}\text { - Low shear forces } \\
\text { - Longer sludge retention } \\
\text { time } \\
\text { - Down-flow gravitational } \\
\text { mode }\end{array}$ & $\begin{array}{l}\text { Pressure gradient } \\
\text { build-up }\end{array}$ \\
\hline Fluidized-bed reactor & $\begin{array}{l}\text { - Large surface area for } \\
\text { SRB growth } \\
\text { - High retention of biomass } \\
\text { - Small pressure gradients } \\
\text { - } \quad \text { Dilute influent } \\
\text { concentrations due to } \\
\text { recycle flow }\end{array}$ & $\begin{array}{l}\text { - Energy needed for } \\
\text { carrier fluidization } \\
\text { - Detaching of } \\
\text { biomass due to shear } \\
\text { force } \\
\text { - Less volume } \\
\text { available for } \\
\text { biomass compared to } \\
\text { UASB reactor }\end{array}$ \\
\hline $\begin{array}{l}\text { Up-flow anaerobic } \\
\text { sludge blanket reactor } \\
\text { (UASB) }\end{array}$ & $\begin{array}{l}\text { - No channeling of flow } \\
\text { - No compacting of sludge } \\
\text { - No clogging } \\
\text { - Possibility to obtain high } \\
\text { treatment rates }\end{array}$ & - Biomass flush out \\
\hline
\end{tabular}

\section{Hydrogen Sulfide}

Hydrogen sulfide $\left(\mathrm{H}_{2} \mathrm{~S}\right)$ is applied in the mining industry for metal sulfide precipitation. The synthesis of $\mathrm{H}_{2} \mathrm{~S}$ can be classified into four main chemical mechanisms, but the preferred method is by sparging hydrogen $\left(\mathrm{H}_{2}\right)$ through liquid sulfur $(\mathrm{S})$.Kwinana nickel factory in Australia is reported to be using a process flow diagram in Figure 1 as their $\mathrm{H}_{2} \mathrm{~S}$ plant. This system was able to produce 4.4 tonnes per day of $\mathrm{H}_{2} \mathrm{~S}$ through this method for nickel extraction processes (Warren, Lee, Morey, \& Zaninovich, 2009). Hydrogen sulfide is toxic and lethal when exposed, making the transportation of $\mathrm{H}_{2} \mathrm{~S}$ to the mining site restricted and costly. An on-site plant production of $\mathrm{H}_{2} \mathrm{~S}$ would be an ideal solution to overcome these limitations, such as the plant in Kwinana nickel factory. 


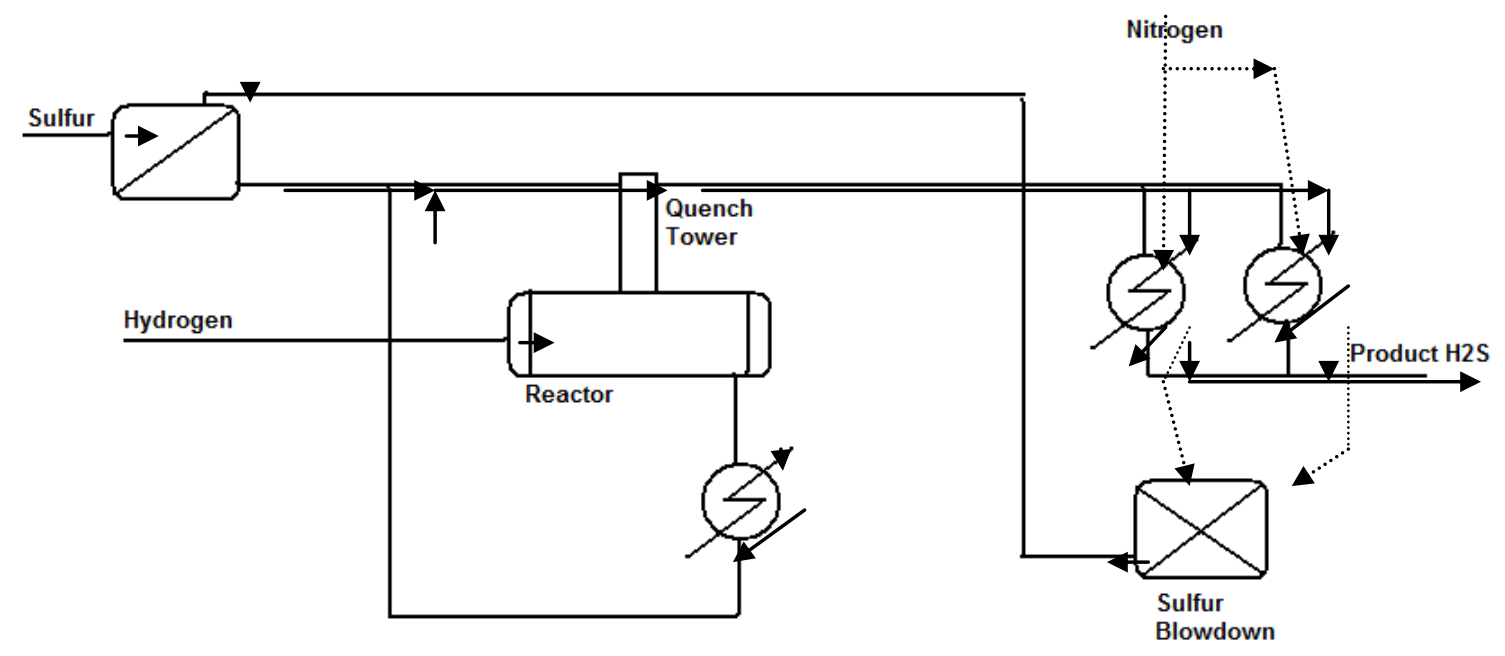

Figure 1. Simplified flow diagram of $\mathrm{H}_{2} \mathrm{~S}$ plant in Kwinana nickel refinery

\section{FACTORS AND LIMITATION OF BIOREACTOR SYSTEM PERFORMANCE}

This section highlights the key parameters that can affect the overall performance and efficiency of the bioreactor system.

\section{Sulfate-reducing Bacteria}

Sulfate-reducing bacteria (SRB) utilize organic carbon for sulfate reduction, while generating biogenic $\mathrm{H}_{2} \mathrm{~S}$ and alkalinity. Eq.(Chandra, Singh, \& Gupta) below describes the mechanism for sulfate reduction by SRB where $\mathrm{CH}_{2} \mathrm{O}$ represents organic carbon.

$$
2 \mathrm{H}^{+}+2 \mathrm{CH}_{2} \mathrm{O}+\mathrm{SO}_{4}^{2-} \rightarrow \mathrm{H}_{2} \mathrm{~S}+2 \mathrm{H}_{2} \mathrm{CO}_{3}
$$

(Chandra et

This results in the precipitation of heavy metals in AMD and an increase in $\mathrm{pH}$ and alkalinity. Biogenic $\mathrm{H}_{2} \mathrm{~S}$ will then react with metallic ions $\left(\mathrm{Me}^{2+}\right)$ present in AMD and forms metal sulfides $(\mathrm{MeS})$, while hydroxide ions $\left(\mathrm{HCO}_{3}{ }^{-}\right)$will react with protons $\left(\mathrm{H}^{+}\right)$to neutralize acidic waters, as explained in the equations below (Kaksonen \& Puhakka, 2007):

$$
\begin{aligned}
& \mathrm{Me}^{2+}+\mathrm{HS}^{-} \rightarrow \mathrm{MeS}+\mathrm{H}^{+} \\
& \mathrm{HCO}_{3}^{-}+\mathrm{H}^{+} \rightarrow \mathrm{CO}_{2}+\mathrm{H}_{2} \mathrm{O}
\end{aligned}
$$

The expected resulting sulfate-reducing environment will include a decrease in sulfate concentration and heavy metals, as well as an increase in $\mathrm{pH}$ and alkalinity (Benner, Blowes, Gould, Herbert, \& Ptacek, 1999; Hulshof, Blowes, Ptacek, \& Gould, 2003).

\section{Microbial Community Structure}

Sulfate-reducing bacteria alone are not capable of oxidizing complex organic compounds and require help from other microbial communities to breakdown complex 
sugar to a simpler form for SRB consumption. There are several types of microbial proponents that act in synergism within the system, which are methanogens, acetogens and sulfate reducers (Neculita, Zagury, \& Bussière, 2007). Competition between microorganisms for available fermentation products is inevitable. However, based on the thermodynamic analysis, SRB are expected to outcompete the acetogens and methanogens for carbon source, provided that sulfate is in excess.

\section{pH}

Sulfate-reducing bacteria favor a $\mathrm{pH}$ range between 6.8-7.2 for optimal growth, as $\mathrm{pH}$ below 5 may inhibit the sulfate process (Lu et al., 2011). However, if a significant production of $\mathrm{H}_{2} \mathrm{~S}$ is to be considered, a pH range of 5 to 6 is needed in order to ensure maximum $\mathrm{H}_{2} \mathrm{~S}$ production.

\section{Organic Substrate}

Availability of carbon sources is the critical limiting factor for SRB reaction. In AMD water, the carbon source is limited and requires additional or external carbon sources for successful treatment (Kolmert, Wikström, \& Hallberg, 2000). Sulfate reduction is an energy-intensive process, which requires a considerable amount of energy-rich reductant (Martins, Faleiro, Barros, Veríssimo, \& Costa, 2009). Hence, selection of suitable carbon sources for bioremediation technology will have an impact on its efficiency and economic viability. Organic matter composition must be considered as it determines the effectiveness of the SRB eco-technology (Gibert, de Pablo, Cortina, \& Ayora, 2002). A substrate must be able to create a suitable low redox environment while serving as a readily-available carbon source. A mixture of readily biodegradable materials with multiple organic carbon sources is more effective at creating the longevity and sustainability of microbial communities (Neculita et al., 2007; Sheoran, Sheoran, \& Choudhary, 2010).

\section{Direct vs. Indirect Organic Substrate}

Simple forms of organic substrates are preferred by SRB as a food source and these can be supplied by either a direct or an indirect method. Direct organic sources such as alcohols, organic acids and sugars are readily available for SRB consumption without having to be further decomposed. Meanwhile, indirect organic sources such as organic compost, wood or paper waste, and food production by-products require further degradation to produce the desired product.As mining sites are located far from urban areas, indirect substrate will be more suitable in long-term situations than direct organic substrate (Sheoran et al., 2010). Even though relatively simple substrates have the advantage of providing a quick and direct utilization of energy sources by SRB, they tend to be used up quickly. Indirectly, substrates need to be continuously fed into the system, thus increasing the operational cost and maintenance (Hiibel et al., 2011).

\section{Hydraulic Retention Time}

A hydraulic retention time (HRT) of 3-5 days has been accepted as allowing sufficient time for sulfide metals to precipitate for direct organic substrate. However, doubling the HRT to 7-10 days has been suggested for indirect organic substrate, to allow sufficient 
time for microbial growth (Alvarez, Crespo, \& Mattiasson, 2007; Chang, Shin, \& Kim, 2000; Gonçalves, Oliveira Mello, \& Costa, 2008).

\section{Temperature}

SRB include both mesophilic and thermophilic strains and are able to survive a temperature range between -5 and $75{ }^{\circ} \mathrm{C}$. Temperature may severely affect the growth and sulfate reduction kinetics of SRB (Tang, Baskaran, \& Nemati, 2009). The performance of sulfate-reducing bacteria depends on the activity of other anaerobic bacteria to degrade complex organic substrate to a simple form. Furthermore, methanogens are sensitive to low temperatures and prefer mesophilic conditions for growth. Therefore, it is expected that the production of biogenic $\mathrm{H}_{2} \mathrm{~S}$ will vary with the season.

\section{Solid Support}

Addition of solid support for SRB may provide positive effects for bacteria growth, thus indirectly increasing the precipitation of metals. Among the materials that have been suggested for solid support are sand, gravel and glass beads (Alvarez et al., 2007; Choudhary \& Sheoran, 2011; Hulshof et al., 2003). It is preferable to select a solid support that has a large pore size, low surface area and large volume of solids in order to reduce plugging in the bioreactor (Sheoran et al., 2010).

\section{Inhibitory Effect}

High concentrations of metallic ions such as iron, zinc, copper and manganese in AMD are toxic and can inhibit the growth of SRB. It has been reported that the lethal range of metallic ions to SRB communities are at: $2-50 \mathrm{mg} \mathrm{Cu} / \mathrm{L}, 13-40 \mathrm{mg} \mathrm{Zn} / \mathrm{L}, 75-125 \mathrm{mg}$ $\mathrm{Pb} / \mathrm{L}$, 4-54 mg Cd/L, 10-20 mg Ni/L, $60 \mathrm{mg} \mathrm{Cr/L,} 74 \mathrm{mg} \mathrm{Hg} / \mathrm{L}$ (Tang et al., 2009). However, these ranges may vary and are dependent on the species of available SRB. The inhibitory effect increases in the following order:

$$
\text { Sulfate }<\text { Thiosulphate }<\text { Sulphite }<\text { Total sulfide }<\mathrm{H}_{2} \mathrm{~S}
$$

\section{BIOGENIC $\mathrm{H}_{2} \mathrm{~S}$ PRECEDENT}

Biogenic $\mathrm{H}_{2} \mathrm{~S}$ productions in the metallurgical process industry have been successfully tested for commercialization.

\section{Copper Queen Mine, Bisbee, Arizona}

A copper plant recovery from low grade leach solution at Copper Queen Mine in Bisbee, Arizona, has been utilizing BiotecQ'sBioSulphide ${ }^{\circledR}$ process technology. This plant uses high rate anaerobic biotechnology for on-site production of $\mathrm{H}_{2} \mathrm{~S}$ from elemental sulfur. The biogenic sulfide produced was used to precipitate copper into a high-grade copper sulfide from pregnant leach solution (PLS) draining from a low grade stockpile (Ashe, McLean, \& McNodwell, 2008). 


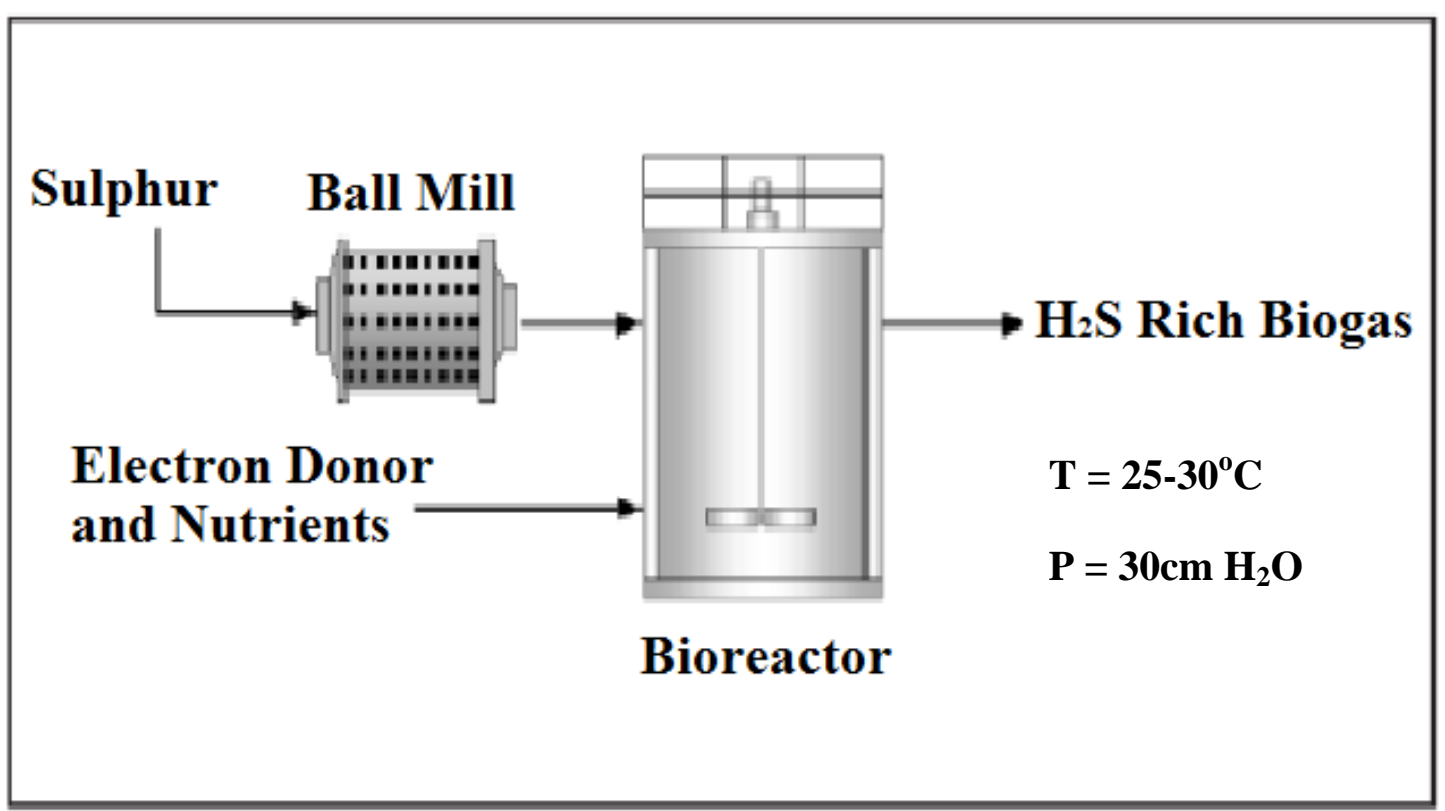

Figure 1. Bisbee PLS composition (Ashe, N.L. et al., 2008).

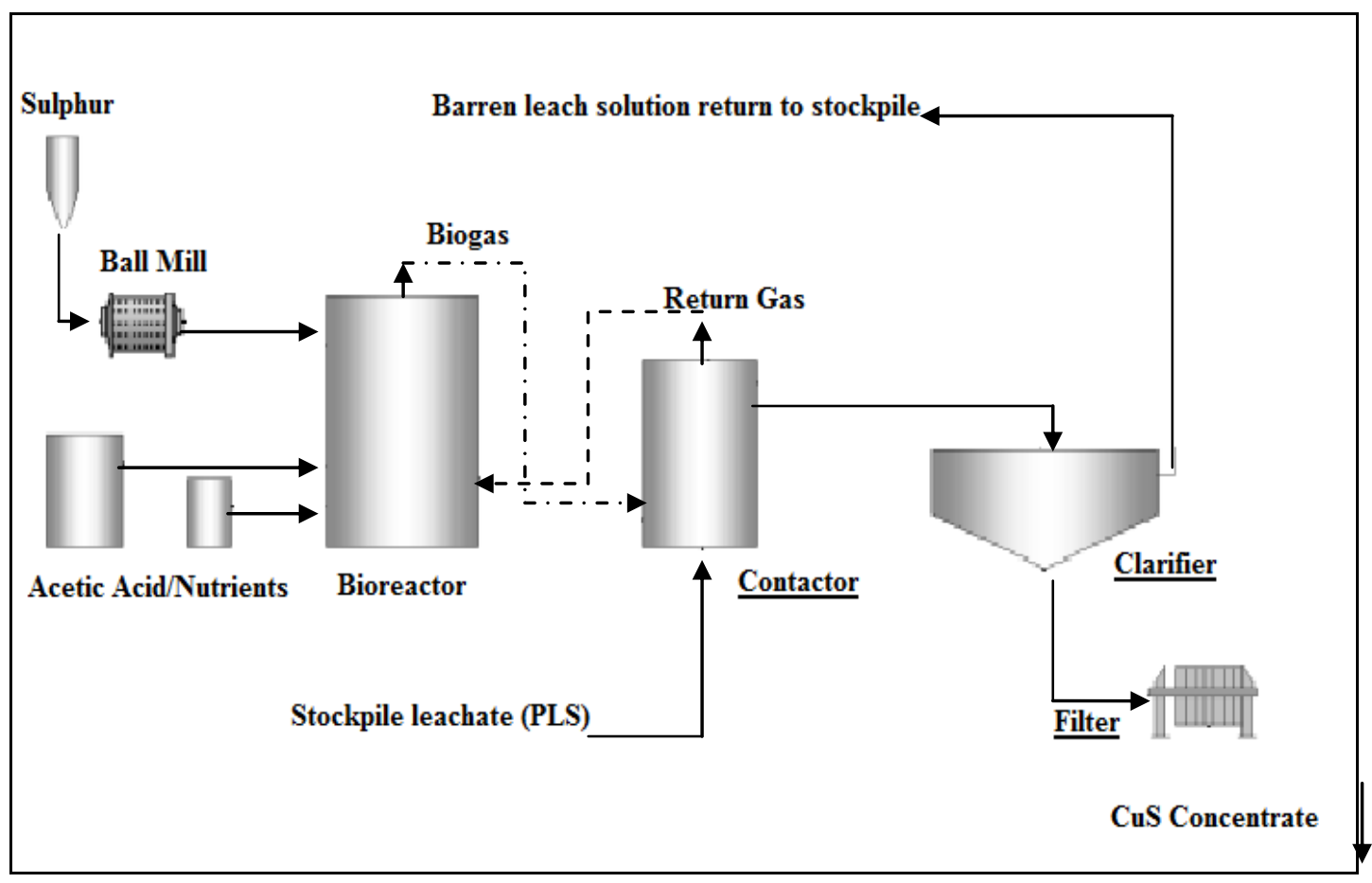

Figure 2.BioSulphide ${ }^{\circledR}$ process in Bisbee (Ashe, N.L. et al., 2008)

The plant was designed to treat 2000 gpm of pregnant leach solution (PLS). Figure 2 shows the typical composition of PLS in the Bisbee plant, and a simplified flow sheet of the sulfide plant at Bisbee is shown in Figure 3. The plant, which comprises a bioreactor, was designed to have a production capacity of 3.4 tonnes of $\mathrm{H}_{2} \mathrm{~S}$ per day. The sulfide gas is then passed to an agitated contactor tank where it is mixed with PLS to precipitate copper. The overall annual maintenance cost to operate the plant is approximately $\$ 135,000 /$ year, which is roughly $4 \%$ of the original capital cost. In the 
first 2 years of operation, the plant recovered on average 63,502 kg/month of copper from the low grade stockpile. The Bisbee plant has been reported to produce sulfides at between $50 \mathrm{~kg} /$ day to 3.7 tonnes/day (Ashe, N.L. et al., 2008).

\section{Kennecott Utah Copper (Ceviz, Koncuk, Küçük, Gören, \& Yüksel), Bingham Canyon, Utah}

Kennecott Utah Copper (Ceviz et al.) operates a vast, integrated mine-mill-smelter refinery complex in Bingham Canyon, Utah, and was reported to produce over 270 kilotonnes of copper annually (van Lier, Buisman, \& Piret, 1999). A demonstration plant was developed by a joint venture between PAQUES and Kennecott to assess THIOPAQ ${ }^{\circledR}$ sulfate and metal removing technology using hydrogen as the electron donor. The demonstration plant was equipped with a $5 \mathrm{~m}^{3}$ hydrogen reactor and was divided into two sections, which are the biological $\mathrm{H}_{2} \mathrm{~S}$ production, and copper recovery from leach water.

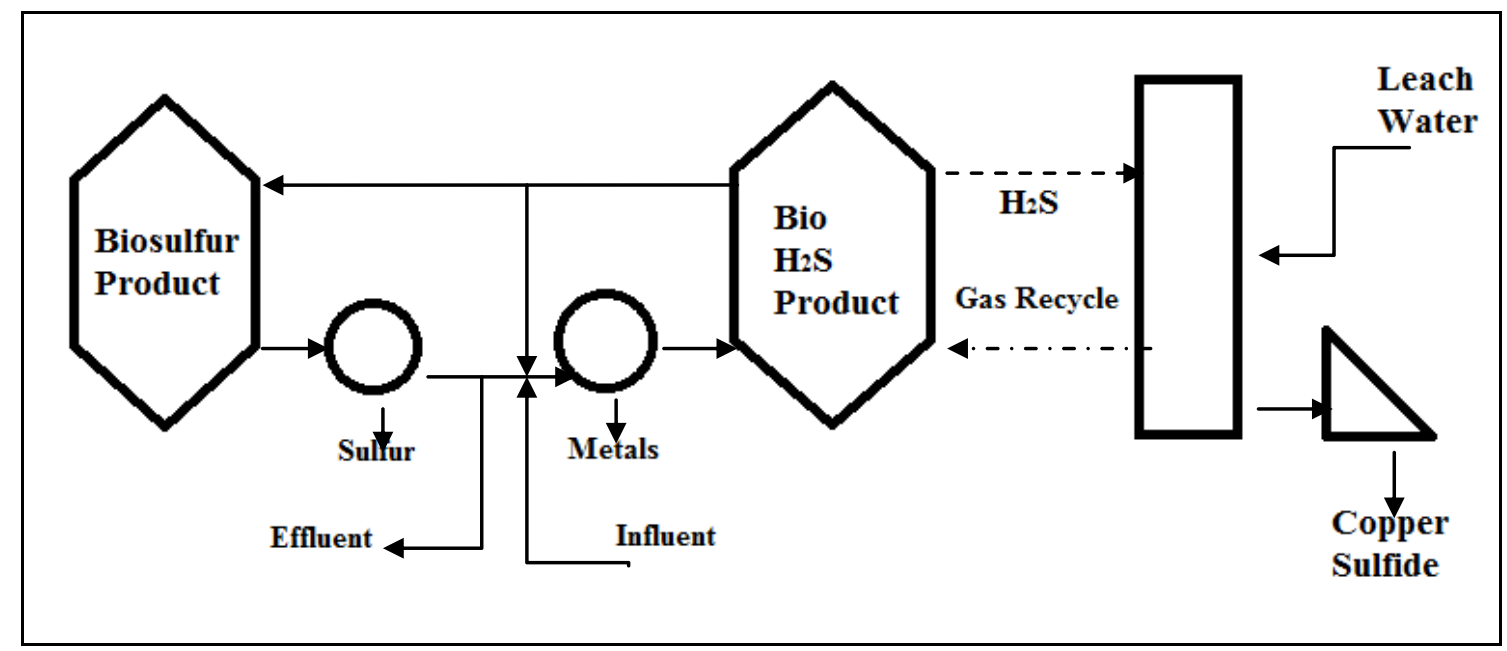

Figure 4. THIOPAQ® demonstration plant at Kennecott (van Lier et al., 1999)

THIOPAQ ${ }^{\circledR}$ technology was able to significantly reduce metal and sulfate concentrations, while increasing the $\mathrm{pH}$ solution from 2.5 to 8.5 without any addition of alkaline. The biogenic $\mathrm{H}_{2} \mathrm{~S}$ gas produced was used for selective recovery of copper from the diluted leach water stream currently treated by cementation and the copper recovery was almost 99.8\% (van Lier et al., 1999).

\section{BIOGENIC $\mathrm{H}_{2} \mathrm{~S}$ PRODUCTION}

The biological process production of $\mathrm{H}_{2} \mathrm{~S}$ has a lower capital cost than chemical processes. This significant cost reduction is because the biological plant uses ambient temperature and pressure in conventional stirred tank bioreactors to produce $\mathrm{H}_{2} \mathrm{~S}$ instead of pressure vessels with expensive agitator seals. The cost of construction of the copper recovery plant in Bisbee was approximately US\$ 3.2 million (Ashe, N.L. et al., 2008). It was reported that the net profits from plant operations and copper sales allowed capital payback in less than 3 years (Ashe, McLean, \& Nodwell, 2008). 


\section{Biogenic $\mathrm{H}_{2} \mathrm{~S}$ Production from Organic Waste}

Commercial biogenic $\mathrm{H}_{2} \mathrm{~S}$ production such as the THIOPAQ ${ }^{\circledR}$ and BioSulphide ${ }^{\circledR}$ technologies utilizes hydrogen, alcohol and acetic acid as carbon sources. These sources are readily utilized by $\mathrm{SRB}$, yielding high $\mathrm{H}_{2} \mathrm{~S}$ in a short amount of time. However, these sources are expensive and require a large expenditure on long-term operation which would put a strain on operational costs. There have been several published reports that utilize various organic solid wastes as the carbon source for SRB; these include wood dust, oak chips and sludge from a wastepaper recycling plant (Goncalves, Mello, $\&$ da Costa, 2007). These waste materials have the advantage of being able to sustain the growth of SRB for long periods without the addition of other substrates.

Table 3. Summary of organic waste as substrate (Gibert et al., 2002).

\begin{tabular}{|c|c|c|c|c|c|c|}
\hline $\begin{array}{l}\text { Source of } \\
\text { organic } \\
\text { matter }\end{array}$ & System & $\begin{array}{l}\text { Sulfate } \\
\text { conc. } \\
\text { (ppm) }\end{array}$ & $\begin{array}{c}\mathrm{T}_{\mathrm{R}} \\
\text { (days) }\end{array}$ & $\begin{array}{l}\text { Additional } \\
\text { carbon } \\
\text { source }\end{array}$ & $\begin{array}{c}\text { Sulfide } \\
\text { production } \\
\text { rate } \\
(\mathrm{mg} /(\mathrm{L} . \mathrm{d}))\end{array}$ & Reference \\
\hline $\begin{array}{c}\text { SRB } \\
\text { culture, } \\
\text { cow } \\
\text { manure, } \\
\text { batch whey }\end{array}$ & Batch & 1000 & - & None & $\begin{array}{c}1-1.5 \text { (total } \\
\text { produced) } \\
0-0.63 \\
\text { (effl. } \\
\text { Content) }\end{array}$ & $\begin{array}{l}\text { (Christensen, } \\
\text { Laake, \& } \\
\text { Lien, 1996) }\end{array}$ \\
\hline $\begin{array}{l}\text { Creek } \\
\text { sediment, } \\
\text { vegetable } \\
\text { compost, } \\
\text { limestone }\end{array}$ & Column & $100 / 500$ & 0.6 & Acetate & 6 & $\begin{array}{c}\text { Not } \\
\text { published }\end{array}$ \\
\hline $\begin{array}{l}\text { Mushroom } \\
\text { compost }\end{array}$ & $\begin{array}{l}\text { Continuous } \\
\text { bioreactor, } \\
\text { sulfide } \\
\text { recirculation }\end{array}$ & n.a. & 4.1 & Lactate & 413 & $\begin{array}{c}\text { (Hammack, } \\
\text { Edenborn, \& } \\
\text { Dvorak, } \\
\text { 1994) }\end{array}$ \\
\hline $\begin{array}{l}\text { Leaf } \\
\text { compost, } \\
\text { pea gravel, } \\
\text { limestone }\end{array}$ & $\begin{array}{l}\text { Full-scale } \\
\text { PBR barrier }\end{array}$ & n.a. & 6 & None & 3.7 & $\begin{array}{l}\text { (Ludwig, } \\
\text { McGregor, } \\
\text { Blowes, } \\
\text { Benner, \& } \\
\text { Mountjoy, } \\
\text { 2002) }\end{array}$ \\
\hline $\begin{array}{l}\text { Municipal } \\
\text { solid waste }\end{array}$ & Batch & n.a. & 180 & None & 1.5 & $\begin{array}{l}\text { (McCullough } \\
\text { \& Lund, } \\
\text { 2011) }\end{array}$ \\
\hline Sugarcane & $\begin{array}{c}\text { Bench-scale } \\
\text { FBR }\end{array}$ & n.a. & 20 & Lactate & 22.2 & $\begin{array}{c}\text { (Choudhary } \\
\text { \& Sheoran, } \\
\text { 2011) }\end{array}$ \\
\hline
\end{tabular}

Waste material that contained polysaccharide seemed to be degraded by hydrolytic fermentative anaerobes to fatty acids and alcohols that support the growth of the sulfidogens (Chang et al., 2000). Another study showed success in metal precipitation using biogenic $\mathrm{H}_{2} \mathrm{~S}$ from volatile fatty acids through microbial hydrolysis 
of papaya, apple and banana (Alvarez et al., 2007). Table 3 presents a summary of the performance of organic waste in sulfide production.

\section{REVIEW OUTCOME AND RECOMMENDATIONS}

\section{Research Gaps on Municipal Solid Waste as Potential Substrate}

Although there have been many reports utilizing organic solid waste as a carbon source for SRB (Choudhary \& Sheoran, 2011; Gonçalves et al., 2008; Martins et al., 2009),most of these reports were based on a batch process.There have been some successful studies performed in continuous culture for sulfide production; however, it was reported that a direct or simple carbon source such as ethanol and acetic acid was used instead of a complex organic waste (Alvarez et al., 2007; Ashe, N.L. et al., 2008). The potential of municipal solid waste (MSW) as an alternative substrate has not been fully understood especially in continuous processes, which leaves a knowledge gap in understanding the performance of organic waste. Municipal solids from green waste showed a lower sulfide production rate than other wastes. Further research will be required to study $\mathrm{H}_{2} \mathrm{~S}$ production using municipal solid waste as a potential substrate for SRB.

\section{Possible Bioreactor System Configuration}

A single stage system consisting of a single bioreactor can be designed for a batch process experiment as shown in Figure 5.

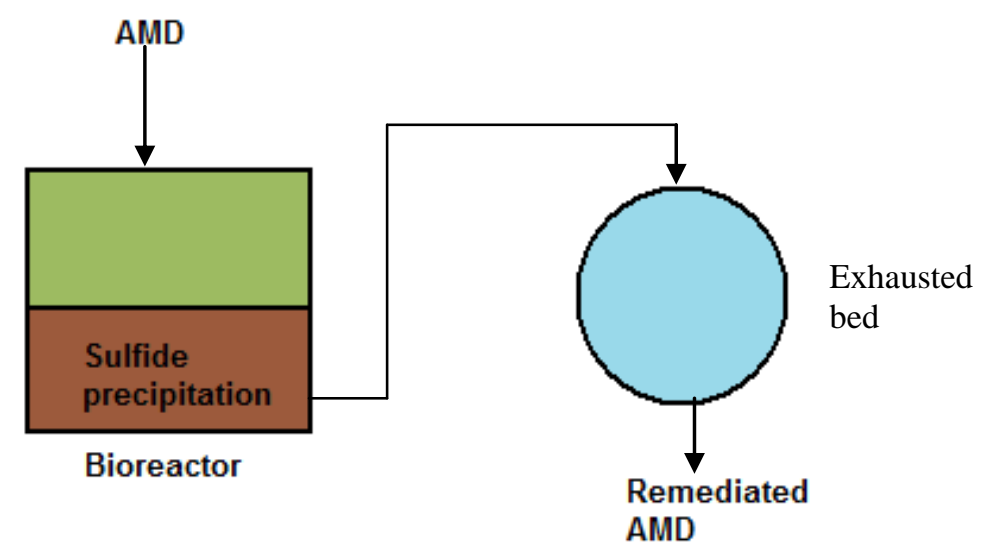

Figure 5. Single stage bioreactor.

Designing a single stage bioreactor such as in Figure 4 will help to understand further the behavior of SRB on the potential carbon source. This batch reactor will also be used to design the modeling of the system. Synthetic AMD will be fed into the bioreactor in Figure 5, which contains SRB, sulfide ions and organic solid waste. Afterwards, precipitate metals in the bioreactor will be collected by overflow in the exhausted bed for further purification. A new and improved system will be designed for a continous process which is shown in Figure 6. The system will consist of three different components, which includea bioreactor, chemical reactor and alkaline reactor. 
The bioreactor will be in an anaerobic condition and the environmental condition will be designed to favor the growth and development of SRB. Reaction between SRB and the carbon source in the bioreactor produces biogenic alkalinity and sulfide ions ( $\mathrm{HS}^{-}$and $\mathrm{S}^{2-}$ ). Afterwards, a recirculating gas stream from the bioreactor will be used to sparge $\mathrm{H}_{2} \mathrm{~S}$ fromthe bioreactor into the chemical reactor,into which AMD waters will also be pumped. Meanwhile, the effluent water from the chemical reactor will flow through the alkaline reactor to increase the $\mathrm{pH}$ to approximately 6 , after which the effluent will flow back into the bioreactor.

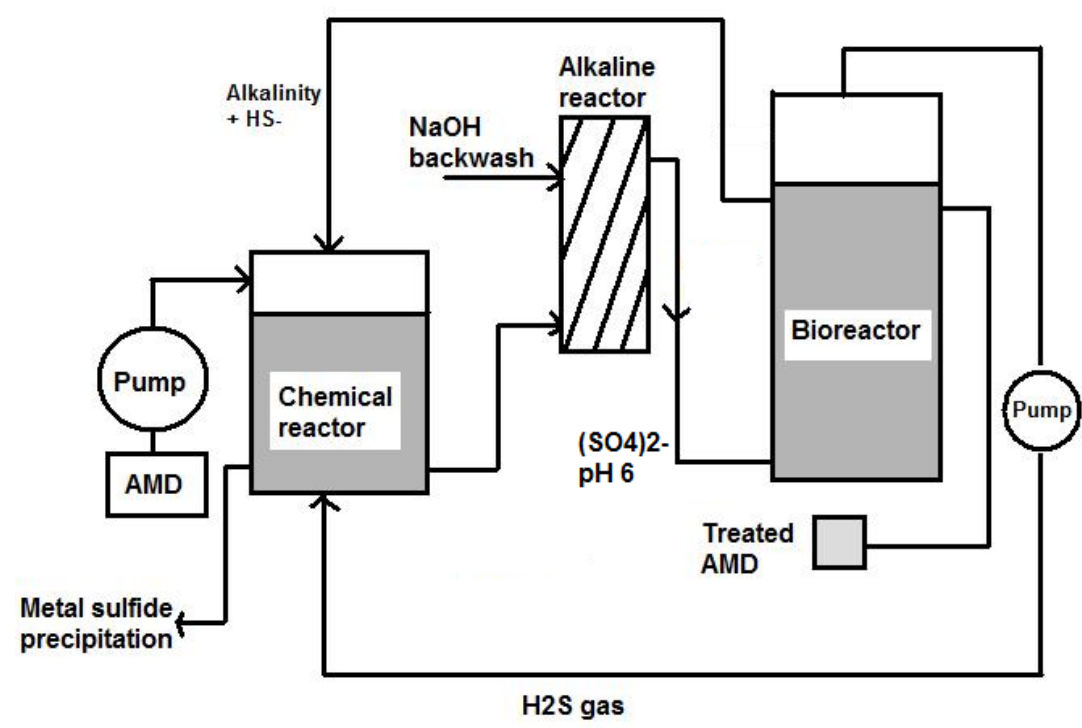

Figure 6. Schematic diagram for sulfide treatment system.

The medium in the bioreactor will be depleted in heavy metals, will contain sulfate, and has an optimal $\mathrm{pH}$ to favor the bacterial growth. The final effluent from the treatment will be left in a U-shaped gas trap at the top of the bioreactor. The system will test the performance of the system when the HRT and flow rate are varied. It is recommended to inoculate bioreactors and allow them to mature before the AMD is fed in to provide long-term provision of organic carbon (Neculita et al., 2007). The suggested configuration of the bioreactor system in Figure 6 was adapted from aprevious study done by McCullough and Lund (2011). Among the improvements suggested is upgrading from a batch to a continuous process, and the separation of the biological and chemical reactors.Demonstration plants such as in Bisbee and Kennecott utilize the BioSulphide ${ }^{\circledR}$ and THIOPAQ ${ }^{\circledR}$ technology and demonstrate that continuous production of $\mathrm{H}_{2} \mathrm{~S}$ is viable provided that the carbon sources are being supplied at a constant rate. By applying a continuous process in the system shown in Figure 6, it is expected that the system will be able to produce a continuous supply of $\mathrm{H}_{2} \mathrm{~S}$, resulting in an optimal recovery of metal sulfides precipitates. Furthermore, improving the design by separating the reactors provides a viable environment for the SRB community for growth activity. Inhibition of the SRB is avoidable since no metallic ions are introduced into the biological reactor. In addition, it is easier to control or change any parameters of the biological reactor with the separation of the chambers. The extraction process of the precious metal sulfides will be less complex since the SRB and metal sulfides are contained in different chambers. This ensures that the SRB are present in abundance within the system, eliminating any lagsor setbacks in the production of $\mathrm{H}_{2} \mathrm{~S}$ should SRB 
be accidentally flushed out of the system. In all, these improvements are expected to give further advantages for this study, especially in creating a sustainable system while producing the maximum amount of $\mathrm{H}_{2} \mathrm{~S}$.

\section{Municipal Solid Wastes as a Potential Carbon Source}

Municipal solid wastes (MSW) are domestic rubbish deposited in landfill sites. It was estimated that $20 \%$ of all solid wastes in Australia were deposited in open dumps (Murdoch University, 2008). Figure 6 represents the analysis of the municipal waste stream in one landfill site in Australia.Food/kitchen and green waste comprised about $22 \%$ and $25 \%$ of the total waste by volume respectively according to a report published by Golder Associates (1999). Assuming the composition of waste in Figure 7 represents most landfill in Australia, recycling and reusing solid waste from municipal landfill as a potential carbon source for sulfate-reducing bacteria could reduce the amount of waste generated by the local population. Furthermore, municipal wastes are abundant and available in towns near to mining sites.

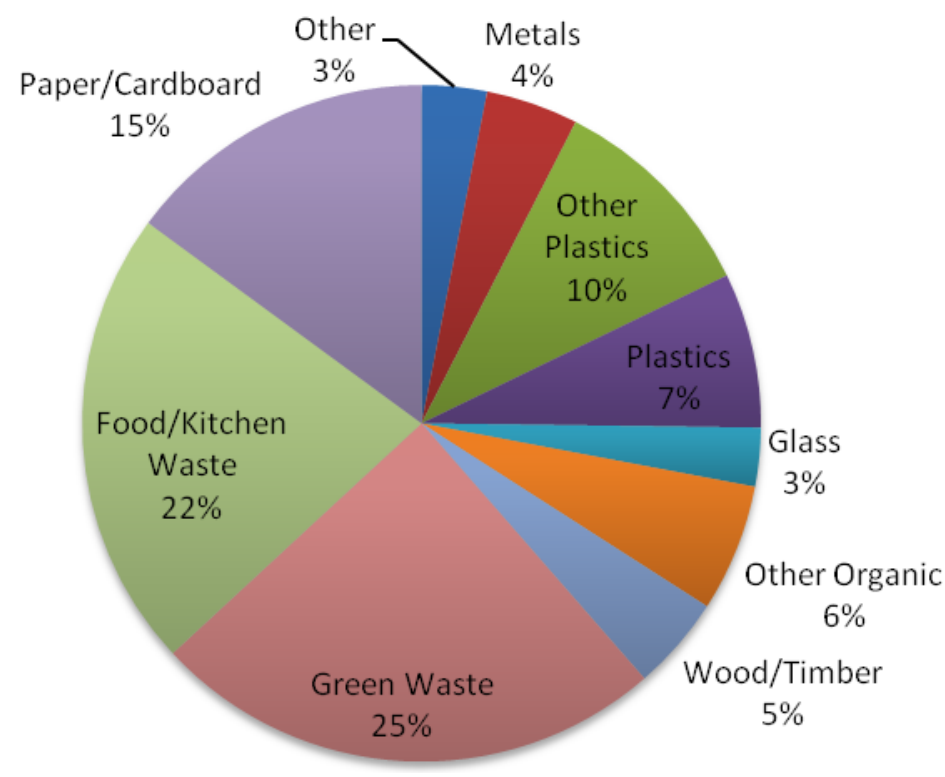

Figure 7. Municipal waste by volume (Golder Associates, 1999)

\section{Amount of waste required}

By referring to the amount of $\mathrm{H}_{2} \mathrm{~S}$ generated daily in the Copper Queen Mine, Bisbee (Ashe, N.L. et al., 2008) and Equation 1, theoretically5.83 tonnes of municipal solid waste per day will be required to produce 3.7 tonnes of $\mathrm{H}_{2} \mathrm{~S}$ per day. This calculation was done on the assumption that SRB utilizes $100 \%$ of solid waste as the carbon source. An example of solid waste collection near mining areas is in Gladstone, Queensland. The municipal solid waste collected at the Benary landfill was 12,500 tonnes in the year 2008-2009 (GRC, 2008-2009). The average collection received was 34.25 tonnes per day. Since it is estimated that 5.83 tonnes of solid waste is required per day to generate 3.7 tonnes of $\mathrm{H}_{2} \mathrm{~S}$ per day, Benary landfill is able to meet the demand for solid waste for 
the large scale bioremediation of AMD. Recycling and reusing solid waste for bioremediation treatment of AMD can reduce negative impacts on the environment.

\section{CONCLUSIONS}

Acid mine drainage causes environmental pollution.and preventing the formation or migration of AMD from its source is generally considered to be the preferred option. Research indicates that bioremediation of AMD that employs sulfate-reducing bacteria has been the subject of interest for many investigators. Previously, research areas have focused on liquid-based substrates (e.g. lactate, ethanol) for sulfidogenic bioreactors. Nevertheless, solid substrate materials have the potential to be a successful substrate supply for sulfate-reducing bacteria systems. However, there is a limited understanding of the behavior of SRB activity with a solid substrate material. The review was able to identify that the rate-limiting factor in sulfate reduction by SRB is the degradation of the complex organics. The overall operational costs of a biological treatment plant are a combination of the system design and location of the plant, profits gained from metal recovery, substrate selection and the discharge criteria. Finding suitable low-cost substrate alternatives such as the use of food waste by-products and organic solid waste may increase the use of SRB technology.

\section{REFERENCES}

Akcil, A., \& Koldas, S. (2006). Acid mine drainage (amd): Causes, treatment and case studies. Journal of Cleaner Production, 14(12-13), 1139-1145.

Alvarez, M. T., Crespo, C., \& Mattiasson, B. (2007). Precipitation of zn(ii), cu(ii) and $\mathrm{pb}$ (ii) at bench-scale using biogenic hydrogen sulfide from the utilization of volatile fatty acids. Chemosphere, 66(9), 1677-1683.

Ashe, N. L., McLean, I., \& McNodwell, M. (2008). Review of operations of biosulphide ${ }^{\circledR}$ process plant at the copper queen mine, bisbee, arizona. Hydrometallurgy 2008 - 6th International Symposium - Honoring Robert Shoemaker, 98-107.

Ashe, N. L., McLean, I., \& Nodwell, M. (2008). Review of operations of the biosulphides(r) bioprocess plant at copper queen mine, brisbee, arizona. Hydrometallurgical, 98-107.

Benner, S. G., Blowes, D. W., Gould, W. D., Herbert, R. B., \& Ptacek, C. J. (1999). Geochemistry of a permeable reactive barrier for metals and acid mine drainage. Environmental Science \& Technology, 33(16), 2793-2799.

Ceviz, M. A., Koncuk, F., Küçük, Ö., Gören, A. C., \& Yüksel, F. (2011). Analysis of combustion stability and its relation to performance characteristics in a compression ignition engine fueled with diesel-biodiesel blends. Energy Sources, Part A: Recovery, Utilization, and Environmental Effects, 33(10), 9901003.

Chandra, R., Singh, S. P., \& Gupta, K. (1999). Damping studies in fiber-reinforced composites-a review. Composite structures, 46(1), 41-51.

Chang, I. S., Shin, P. K., \& Kim, B. H. (2000). Biological treatment of acid mine drainage under sulphate-reducing conditions with solid waste materials as substrate. Water Research, 34(4), 1269-1277. 
Choudhary, R. P., \& Sheoran, A. S. (2011). Comparative study of cellulose waste versus organic waste as substrate in a sulfate reducing bioreactor. Bioresource Technology, 102(6), 4319-4324.

Christensen, B., Laake, M., \& Lien, T. (1996). Treatment of acid mine water by sulfatereducing bacteria; results from a bench scale experiment. Water Research, 30(7), 1617-1624.

Gibert, O., de Pablo, J., Cortina, J. L., \& Ayora, C. (2002). Treatment of acid mine drainage by sulphate-reducing bacteria using permeable reactive barriers: A review from laboratory to full-scale experiments. Reviews in Environmental Science and Biotechnology, 1(4), 327-333.

Gonçalves, M., Oliveira Mello, L., \& Costa, A. (2008). The use of seaweed and sugarcane bagasse for the biological treatment of metal-contaminated waters under sulfate-reducing conditions. Applied Biochemistry and Biotechnology, 147(1-3), 97-105.

Goncalves, M. M. M., Mello, L., \& da Costa, A. (2007). The use of seaweed and sugarcane bagasse for biological treatment of metal-contaminated waters under sulfate-reducing conditions. Application Biochemical Biotechnology(147), 97105.

Government, A. (2007). Managing acid and metalliferous drainage (Resources, D. o. I. T. a., Trans.).

Government, Q. S. (2011). Waste reduction and recycling bill 2011. Queensland.

GRC. (2008-2009). Gladstone regional council. Annual report.

Hammack, R. W., Edenborn, H. M., \& Dvorak, D. H. (1994). Treatment of water from an open-pit copper mine using biogenic sulfide and limestone: A feasibility study. Water Research, 28(11), 2321-2329.

Hiibel, S. R., Pereyra, L. P., Breazeal, M. V. R., Reisman, D. J., Reardon, K. F., \& Pruden, A. (2011). Effect of organic substrate on the microbial community structure in pilot-scale sulfate-reducing biochemical reactors treating mine drainage. Environmental Engineering Science, 28(8), 563-572.

Hulshof, A. H., Blowes, D. W., Ptacek, C. J., \& Gould, W. D. (2003). Microbial and nutrient investigations into the use of in situ layers for treatment of tailings effluent. Environ Sci Technol, 37(21), 5027-33.

Kaksonen, A. H., \& Puhakka, J. A. (2007). Sulfate reduction based bioprocesses for the treatment of acid mine drainage and the recovery of metals. Engineering in Life Sciences, 7(6), 541-564.

Kolmert, Å., Wikström, P., \& Hallberg, K. B. (2000). A fast and simple turbidimetric method for the determination of sulfate in sulfate-reducing bacterial cultures. Journal of Microbiological Methods, 41(3), 179-184.

Lu, J., Chen, T., Wu, J., Chris Wilson, P., Hao, X., \& Qian, J. (2011). Acid tolerance of an acid mine drainage bioremediation system based on biological sulfate reduction. Bioresource Technology, 102(22), 10401-10406.

Ludwig, R. D., McGregor, R. G., Blowes, D. W., Benner, S. G., \& Mountjoy, K. (2002). A permeable reactive barrier for treatment of heavy metals. Ground Water, 40(1), 59-66.

Martins, M., Faleiro, M., Barros, R., Veríssimo, A., \& Costa, M. (2009). Biological sulphate reduction using food industry wastes as carbon sources. Biodegradation, 20(4), 559-567. 
McCullough, C., \& Lund, M. (2011). Bioremediation of acidic and metalliferous drainage through organic carbon amendment by municipal sewage and green waste. Journal of Environmental Management, 92(10), 2419-2426.

Neculita, C.-M., Zagury, G. J., \& Bussière, B. (2007). Passive treatment of acid mine drainage in bioreactors using sulfate-reducing bacteria. J. Environ. Qual., 36(1), $1-16$.

Peppas, A., Komnitsas, K., \& Halikia, I. (2000). Use of organic covers for acid mine drainage control. Minerals Engineering, 13(5), 563-574.

Sheoran, A. S., Sheoran, V., \& Choudhary, R. P. (2010). Bioremediation of acid-rock drainage by sulphate-reducing prokaryotes: A review. Minerals Engineering, 23(14), 1073-1100.

Sundar Raj, C., \& Sendilvelan, S. (2010). Effect of oxygenated hydrocarbon additives on exhaust emission of a diesel engine. International Journal of Automotive and Mechanical Engineering, 2, 144-156.

Tang, K., Baskaran, V., \& Nemati, M. (2009). Bacteria of the sulphur cycle: An overview of microbiology, biokinetics and their role in petroleum and mining industries. Biochemical Engineering Journal, 44(1), 73-94.

Tangjitsitcharoen, S., \& Nunya, N. (2011). Reduction of oil contamination on hard disk drive parts using automatic hydrocarbon washing machine. Journal of Mechanical Engineering and Sciences, 1, 113-123.

van Houten, R. T., Pol, L. W. H., \& Lettinga, G. (1994). Biological sulphate reduction using gas-lift reactors fed with hydrogen and carbon dioxide as energy and carbon source. Biotechnology and Bioengineering, 44(5), 586-594.

van Lier, R. J. M., Buisman, C. J. N., \& Piret, N. L. (1999). Thiopaq(r) technology: Versatile high-rate biotechnology for the mining and metallurgical industries.

Warren, M., Lee, M., Morey, J., \& Zaninovich, S. (2009). Replacement h2s plant for kwinana nickel refinery. Engineering Our Future: Are We Up To The Challange. 